\title{
Why is a Change of Company Pricing Policy so Hard to Implement?
}

\author{
Pierre van der Rest, Angela Roper, Xuan Lorna Wang. (2018) \\ International Journal of Hospitality Management, 69, January, 30-40.
}

\begin{abstract}
This paper analyzes the process of changing a competition-oriented room rate pricing approach into a company-wide value-based pricing process from the perspective of the resource-based view. From a sample of 33 hotels in 16 countries it evaluates data from 55 open-ended interviews, documentation and archival records. Employing systems methodology the study illustrates that pricing is an intra/inter-organizational activity involving crossdisciplinary processes at various hierarchical levels. It finds that changing to value-based pricing involves a remarkable level of especially intangible resources. The study identifies these resources and their impact, identifying how constraints and tensions influence the shift in pricing orientation. It suggests that pricing in a value-driven policy comprises a capability. Without this capability interpersonal realities and goal conflicts, most prominently between sales and revenue, are found to impose major effects on the alignment of functional levels, the change in pricing processes, and the degree to which these are really value-driven.
\end{abstract}

Key words: resource-based view, capability, value-based, pricing, sales, revenue management 


\section{Why is a Change of Company Pricing Policy so Hard to Implement?}

\section{Introduction}

Over the years, room rate pricing has received continuous research attention in the hospitality management literature. While initially conceptual in nature (e.g., Gu, 1997; Kim, Han \& Kyun, 2004), a wide variety of topics have been empirically investigated, such as 'oligopoly pricing' (e.g., Baum \& Mudambi, 1995), ‘price fairness' (e.g., Oh, 2003), ‘pricing strategy’ (e.g., Enz, Canina \& Lomanno, 2004), 'online pricing' (e.g., Tso \& Law, 2005), or, more recently, 'price determinants' (e.g., Zhang, Ye \& Law, 2011), 'price modeling' (e.g., Zhang, Zhang, Lu, Cheng \& Zhang, 2011), 'dynamic pricing' (e.g., Abrate, Fraquelli \& Viglia, 2012), ‘competitive pricing’ (e.g., Becerra, Santaló \& Silva, 2013), 'price cues’ (e.g., Noone \& McGuire, 2013), 'third party pricing' (e.g., Guo, Ling, Dong \& Liang, 2013), and 'price bundling' (e.g., Repetti, Roe \& Gregory, 2015). Despite the amount of research, little attention has been paid to room rate pricing as a 'strategic process': the human and social activity, influenced by its organizational and environmental context, which affects company performance. As an exception, Pellinen (2003) studied the pricing routines of two hotels in Lapland. He found that room rate pricing was an ongoing and planned annual team activity, a holistic, creative and intuitive process driven by a formal revenue management system mixed with trial-and-error methods. Pellinen (2003) established three categories of pricing decisionmaking routines, the: (1) imitator; (2) customer enticer; and (3) strong calculator. These routines were strongly affected by external and internal stakeholders, including the managers of other hotels (i.e., regional and inter-regional network context) and decision-makers within the hotel chain. However, this study is dated and lacks a theoretical foundation to explain why these pricing activities occur.

Pricing as a 'strategic process' has been more recognized in the generic business literature. For example, Vorhies and Harker (2000) found a direct positive relationship 
between the processes needed to set prices and superior firm performance. Moreover, Vorhies (1998) found that the relationship between information processing capabilities and performance was mediated by pricing (as part of marketing capabilities development). Pricing also arbitrated the relationship between product-market strategy and business unit performance (Vorhies, Morgan, \& Autry, 2009). In addition, Dutta, Zbaracki and Bergen (2003) found that firms can capture value by combining and developing pricing resources in ways that improve pricing processes and, hence, prices and revenue. In particular, they stressed the importance of comparative advantages in pricing resources in the pursuit of superior performance. Their findings were supported by Blyler and Coff (2003), who suggested that the informational benefits of managerial ties with customers and suppliers optimized pricing, and by Kemper, Engelen, and Brettel (2011), who found that pricing processes were significantly influenced by top management's social capital, a relationship which was negatively moderated by power distance. In this way, a strategic perspective on pricing draws attention to what is perhaps most relevant to pricing: the actual means necessary to determine price (Van der Rest \& Roper, 2013). That is, the literature is gradually accepting of the notion that it is not only variations in price that should be explained (in models), as there are so many prices possible at different points in time, but that pricing processes should be given more research priority.

What is still missing, however, is a series of in-depth case studies that provide insights into pricing at the individual level to stimulate broad theoretical discussions on the behavioral effects that shape pricing activities, processes and resources in an organization. Descriptive analyses of this internal perspective, as a first start, are vital to gain a better understanding of the variety of pricing behaviors and environments that exist, and, in turn, for theory development (Cyert \& Hedrick, 1972; Monroe \& Mazumdar, 1988). In the words of Earl (1990, p. 277): 


\begin{abstract}
A behavioral perspective suggests that the forces likely to shape pricing decisions are much more complex than parties on either side of debate over marginalism are usually willing to admit. Complexity may be expected to [...] vary in different contexts, [...]. Hence the pricing behavior of firms in a particular industry may be easy to explain in terms of a given pricing rule, and yet difficult to reconcile with another rule that seems to match observations in other sectors or in the same sector at different points in time.
\end{abstract}

Thus, an essential research step is to 'document the pricing practices encountered in various products and markets' (Raviv, 1984, p. 37).

Therefore, this paper explores how human interactions and human behavior at various organizational levels influence room rate pricing processes in a European hotel group. The study utilizes arguments that follow from the resource-based view to analyze how individuals who comprise the organization strategically deal with pricing (Dutta et al., 2003; Liozu \& Hinterhuber, 2013). In so doing the paper answers to Cross, Higbie, and Cross (2009) who argue that a move away from just opening and closing room rates to a deeper strategic understanding of "right pricing" is essential for hotel revenue management. As pricing in the hotel industry is inherently competitor-oriented (Enz, Canina \& Van der Rest, 2016), and value-informed pricing still weakly grounded in theory (Ingenbleek, 2014), an European hotel group was investigated that was attempting to strategically change its cross-country pricing practices to a value-driven approach. In this way, the paper also answers to Ingenbleek (2002, 2014) who calls for more qualitative research and case studies, especially detailed work on cross-national, cross-cultural differences in pricing practices, institutional barriers to pricing competence development, and industries not previously examined. The paper begins by reviewing previous research on pricing processes. This is followed by a justification of the methodology. Next, the findings are reported and discussed. The paper concludes with implications for theory and practice, and provides directions for future research. 


\section{Literature Review}

Early investigations on pricing processes can be found in the economic literature (e.g., Hall \& Hitch, 1939; Kaplan, Dirlam \& Lanzillotti, 1958; Hague, 1971). This literature on price behavior challenged the profit-maximization assumption of the theory of the firm, and, thus, disagreed with the widely accepted marginal rules of behavior. Therefore, it tended to concentrate on the normal cost hypothesis, strategic interaction and the procedure for calculating prices rather than investigating pricing as a social and human interactive process. As collective price agreements were gradually outlawed, firms were forced to look afresh at their pricing practices. This initiated a whole new range of non-empirical papers prescribing how businessmen should set prices (e.g., Dean, 1949; Oxenfeldt, 1960). Much of the earlier work on room rate pricing was of this nature, especially during the 1990s (e.g., Dunn \& Brookes, 1990; Lewis \& Shoemaker, 1997). Moreover, akin to the price behavior literature in economics a new line of work (in marketing) emerged seeking to empirically determine the relevance of different pricing factors, objectives and methods, in particular the widespread existence of cost and competitor orientations in pricing (e.g., Udell, 1964; Nimer, 1971; Abratt \& Pitt 1985; Tzokas et al., 2000). Offering limited practical guidance these studies dominated the generic pricing literature for many years.

A number of studies deviated from the neoclassical approach in economics including those by Morgenroth (1964), Farley, Howard and Hulbert (1971), Capon, Farley and Hulbert (1975), Farley, Hulbert and Weinstein (1980), Bonoma, Crittenden and Dolan (1988), and Carson et al. (1998). The central weakness of this descriptive research was that it did not relate specific observations to general patterns in order to formulate hypotheses that could be explored, tested and finally developed into general conclusions and theories. However, in three studies, Dutta, Zbaracki, and Bergen (2001), Dutta, Bergen, Levy, Ritson, and Zbaracki (2002), and Dutta, Zbaracki, and Bergen (2003) reported a more theory-guided analysis of 
pricing. Their studies were novel in terms of being a first attempt to conceptualize the pricesetting process using arguments that followed from the behavioral theory of the firm, evolutionary theory, and the resource based view of the firm. In the view of Dutta et al. (2003), in addition to competing through value-creating resources, firms also competed by investing in value-capturing resources. As these resources were not easily imitated, traded for, or substituted for, they found that pricing was a capability. This capability required extensive investment in time, effort, technology and staff. Advantages of these investments were only recognized after years as confidence and benefits accumulated. Benefits included an increase in know-how, tangible and intangible skills, as well as creativity in solving pricing problems. As a result, the authors concluded that 'a theory of the process by which prices are determined must address the different resources and capabilities required to set and change prices' (Dutta et al., 2003, p. 618). In a (quantitative) response, Liozu and Hinterhuber (2014) validated a specific scale to measure pricing capabilities, as pricing in the context of financial performance had only been measured as a subset of marketing capabilities (e.g., Zou et al., 2003; Vorhies \& Morgan, 2005; Morgan et al., 2009, Kemper et al., 2011). Three years later, in a special issue of the Journal of Business Research, Töytäri, Keränen, and Rajala (2017) and Hallberg (2017) further explore the development of pricing capabilities by investigating how individual activities and personality traits influence pricing activities at the organizational level. Highlighting the strategic nature of pricing, Hallberg (2017, p.1) finds that 'individual judgment, human capital, and commercial experience' are crucial in implementing a pricing strategy. Moreover, in a study focusing on barriers to implementing value-based pricing, Töytäri, Keränen, and Rajala (2017) identify three types of barriers that individuals need to overcome: individually, organizationally, and externally induced barriers. Despite this increased attention for pricing as a strategic organizational process, Hinterhuber 
and Liozu (2017, p.2) conclude that the literature is still very much in its infancy, as 'these papers barely scratch the surface of this rich and complex domain'.

'What applies to a single-market setting holds even more true for pricing in a global marketing context' (Stöttinger, 2001, p. 40). As Sharp (1994, p. 132) stated: 'in multinational corporations (MNCs) price management is especially complex because pricing choices have to be made under joint complexity of environmental uncertainty arising from both exchangerate volatility and changing global competitiveness, and the intra-organizational diversity typical of large MNCs servicing worldwide markets with many products'. It is this crossfunctional, cross-border, and cross-disciplinary complexity for which executives most wish to have guidance (Kinnear, 1999). Pricing practice research in international business, however, has received scant attention. Research in this area has been largely conceptual (e.g., Walters, 1989), with some rare exceptions. For example, Stöttinger (2001) found that international business executives did not employ separate objectives for pricing decisions. The success or failure of pricing was only derived from overall performance. In nearly all firms MDs or CEOs decided on international prices. In a subsequent study Solberg et al. (2006) examined the information use, strategic approach, and managerial control behavior in the export practices of 24 firms based in Austria, Norway, and the United States. They found that information sources tended to become more varied and sophisticated as a firm became more internationalized. The same positive relationship was observed with reference to the degree of price control. Furthermore, they concluded that pricing issues were relatively universal and not culture bound. What these studies, however, failed to provide is a behavioral understanding for pricing practices. As a rare exception, Lancioni et al. (2005) examined the internal political system - reflecting interdepartmental coordination and rivalry - of 125 firms listed in the Fortune 1000. They found that different departments hindered the development of pricing as a capability differently: finance for its general inclination to control, accounting for 
its delays in providing cost information and its insistence on using cost-plus pricing, sales for its independent and nonconformist behavior, production for insisting on (too) large quantities when designing special promotions, marketing for its reluctance to respond to market changes and its rigidity in executing the marketing plan, and customer service for causing confusion by frequently misquoting prices to customers. They also found that to remove departmental barriers it was necessary to: (1) think of pricing as a strategic activity; and (2) convince finance that full cost recovery must be done over the long-term.

Whereas there is scant attention for pricing as an internal process in the hospitality management literature, hotel revenue management acknowledges the importance of human and organizational processes in the pursuit of company performance. As Yeoman and Watson (1997, p.80) argued, 'the process of managing yield is basically a human activity'. In the words of Schwartz and Cohen (2004, p.85), 'the best computer-generated recommendations might be suboptimal and require adjustments based on human judgment'. And, a decade before, Jones and Hamilton (1992, p.95) already explained, 'a successful yield-management system depends on people as much as on sophisticated technology'. Or, as Wang, Heo, Schwartz, Legohérel and Specklin (2016, p. 808) explain:

One of the major challenges faced by RM practitioners is how to look beyond traditional tactical RM techniques as part of operations management and incorporate RM at the strategic level in order to proactively engage with other management areas across the organization internally and with customers externally. [need ending here and link to next section]

Indeed, when hotel revenue management evolves to a more strategic (marketing) approach (Kimes, 2016), the development of capabilities will be key, especially when human judgment is required to enable revenue management decision-making in a context (e.g., Abrate \& Viglia, 2016; Lee, 2016). This research attention for pricing as a process, however, is somewhat fragmented, with work stemming from a diverse range of paradigms, each with 
their own concepts and theories, methodologies and epistemologies. What thus is needed, is an approach that shares affinities with multiple research traditions to preserve the cumulativeness of the current body of knowledge.

\section{Methodology}

The study adopted a modern systems approach related to the philosophy of Scientific Realism (Harré, 1986). Scientific Realism accepts that all terms may be theoretical, a key property of resource-based theory. Its ontological position implies that if it is not believed that intentional human action and interaction affect how international organizations deal with a change in pricing policy, then any attempt to explore how individual characteristics, processes and resources produce value-driven pricing decisions, is irrational. Adopting systems methodology implied assuming that reality was objectively accessible but different from the sum of its parts. As a result, pricing activities were understood through the characteristics of the larger whole in which they served a purpose. The systems approach thus acknowledged the role of social behavior not present in conventional price theory. It permitted the identification and categorization of fundamental processes and resources constituting (un)observable entities previously unrecognized or overlooked. Given this complex-pluralist type of research problem context, as derived from the ideal-type grid advanced by Jackson and Keys (1984), Flood and Jackson (1991), and Jackson (1993, 2000), soft systems methodology (SSM) was chosen as the systems analysis approach.

The case study design was identified as suitable since, for this study, it allowed for an understanding of the behavioral foundations of value-based pricing in a real-life context (Morris \& Wood, 1991; Hamel et al., 1993; Stake, 2000). It was preferred over other research strategies as it accommodated the examination of contemporary events when relevant behaviors could not be manipulated (Yin, 2014). The case study strategy corresponded with 
Churchman (1979) who argued that it is ideal for systems analysis, and with Tsoukas (1989) who argued for case studies from a Scientific Realism viewpoint. The study design included three types of enquiry: (1) an exploration to find out what was happening and to seek insights into pricing behavior; (2) the detailed description of value-based pricing procedures and processes; and (3) determination of finality relations to understand the utilization of pricing resources. It was anticipated that to develop an in-depth understanding of the individual activities, processes and resources that affect value-based pricing, it would be necessary to investigate the change in pricing practices at both the head-office, regional and hotel property level. The case study strategy, therefore, took the form of a (revelatory) single-case study with embedded multiple units (i.e. the hotel properties formed lesser units than the case itself).

The investigation took place in one of the fastest growing hotel groups in Europe. The group was particularly attractive as it was implementing a group-wide value-based pricing policy which offered an opportunity to gain a 'unique' case example. One of its 4-star upscale brands, comprising owned, leased, managed and franchised hotels, became the object of the study. The case study strategy included gaining data from 33 hotels located in 18 cities in 16 countries in Europe. The size of the hotels ranged from small (46 rooms) to large (673 rooms). Purposive heterogeneous sampling was used to select the properties. Its logic laid in selecting informationrich pricing practices for in-depth study (Patton, 1990). Heterogeneous sampling was used 'to collect data to describe and explain the key themes' that could be observed (Saunders et al., 2000, p.174). To ensure maximum variation within the sample, selection criteria included the relative quality of property, experience of the 'pricing team', structure of the organization, type of operation, opening date, and type of room inventory. The selection was thus 'made on conceptual grounds, not on representative grounds' (Miles \& Huberman, 1994, p.29). Prior to the main study a pilot case study was carried out to test and refine the research methodology. 
The exploratory nature of the research topic, as well as the intangible nature of pricing resources, required a qualitative method (Strauss \& Corbin, 1998; Ingram, 1999; Maxwell, 1996). 55 semi-structured open-ended interviews were conducted. To select the respondents a purposive homogeneous sampling technique was used. It was decided to gain data from four groups of managers at all organizational levels: (1) general managers; (2) revenue managers; (3) sales managers; and (4) financial controllers.

To corroborate interview data with information from other sources, access was obtained to memoranda's, business plans, e-mails and other on-site materials including training and policy documentation. Obtaining triangular evidence required 'reading between the lines'. The data saturation that occurred through the extensive amount of interviews in combination with an elaborate literature review that was carried out, however, gave confidence to believe that something like the processes and resources (i.e. inductive realism) truly said something intersubjectively certifiable about value-based pricing in the hotel group (Hunt, 2002). Alternative triangulation methods were considered, but the project's cross-sectional data structure limited the use of other techniques, such as observation.

The data analysis adopted logic-driven techniques from soft systems methodology including drawing rich pictures and producing a root definition of the real system (Checkland, 2003). The mnemonic CATWOE was used to aid the definition process. Once the root definition was identified, a (number of) conceptual model(s) were constructed according to a four-step sequence. The main tasks included the organization of data and the generation of categories, themes and patterns. Another task was to link the results into the existing body of knowledge 'to get started' and to provide an initial analytical framework. Using the insights obtained from the literature review as a 'skeleton', and by applying the theoretical framework of Van der Rest and Roper (2013), the behavioral foundations of the value-based company pricing policy were further analyzed from a resource-based perspective. In this way, an 
attempt was made to overcome the criticism of especially the early pricing case studies (e.g., Hague, 1971, Pellinen, 2003) which have commonly been addressed as raw empiricism (Diamantopoulos \& Mathews, 1995).

\section{Findings}

The findings are structured into three parts. Firstly, an initial overview of the organizational context in which room rate pricing in a European hotel group takes place is presented. It identifies the key players and organizational levels of the process. It also provides information of the formal group policy and develops a matrix to disentangle room rate pricing processes in the hotel group. Secondly, the main processes employed are examined through systems modeling, with separate (but integrated) models constructed based on accounts of concepts purposeful acidity through the group. Thirdly, the activities required for implementing valuebased pricing activities are explored.

\section{Organizational context}

The study illustrates that issues regarding the new value-based pricing policy are discussed, interpreted and processed at different levels in the European hotel group. As a crossdisciplinary team activity, experts in sales and marketing, revenue management, accounting and general management all contribute. Figure 1 presents the key players in the pricing decision-making process. 


\section{Figure 1: Interactions between Key Player's Pricing Processes}

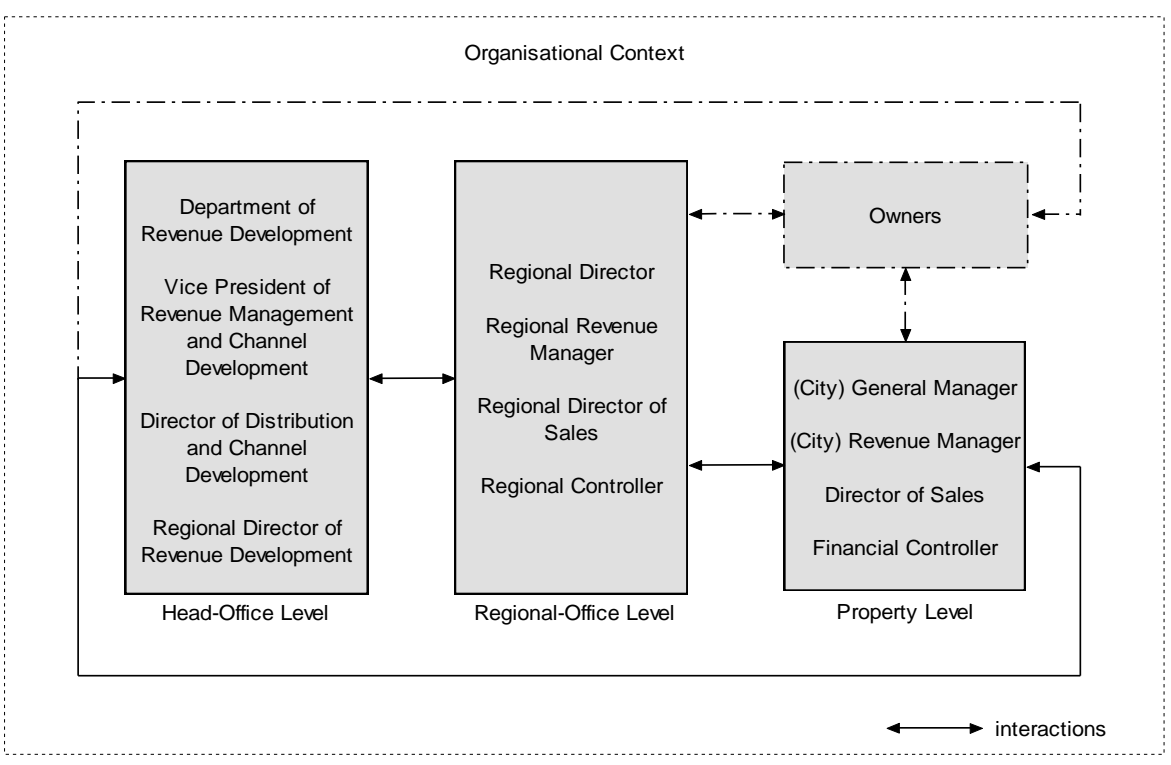

Interactions between head-office, regional office, and property level can initially be associated with a pricing occurrence. Pricing decisions with consequences for annual business planning processes generally involve all three levels. Decisions involving daily pricing activities typically occur at the property level. General Managers are considered to be the owners of these processes. They are responsible for the profitability of a property and consequently for all decisions in room rate pricing. General management directly answers to head-office. When the ownership of a hotel lies with an external party, general management is also accountable to the property owners. Regional office plays an important intermediating role. Depending on the business context, it may act as an intermediary between property management and external owners.

Room rate pricing processes were found to vary depending on the hierarchical level and planning horizon. Table 1 illustrates a division of processes at different levels - property, regional office or head-office (bottom axis). It also displays the processes related to room rate decisions made annually, monthly and bi-monthly and on a daily basis (horizontal axis). The 
processes involved are grouped together into seven cells and can be cross-tabulated based on where they are hierarchically located and in which time horizon.

Table 1: Division of Pricing Processes

\begin{tabular}{|c|c|c|c|}
\hline Annually & $\begin{array}{l}\text { - determining pricing strategy } 1 \\
\text { - prospecting and contracting }\end{array}$ & $\begin{array}{l}\text { - transmitting corporate pricing policy } 4 \\
\text { - prospecting and contracting }\end{array}$ & - approving property pricing strategy 6 \\
\hline $\begin{array}{l}\text { e.g. Monthly } \\
\text { or biannually }\end{array}$ & \begin{tabular}{|l|} 
- adjusting pricing strategy 2 \\
- prospecting and contracting
\end{tabular} & $\begin{array}{l}\text { - pricing control and support } \\
\text { - prospecting and contracting }\end{array}$ & $\begin{array}{l}\text { - approving property pricing strategy } 7 \\
\text { - pricing control and support }\end{array}$ \\
\hline Daily & \begin{tabular}{|l|} 
- fine-tuning and learning \\
- prospecting and contracting \\
\end{tabular} & & \\
\hline
\end{tabular}

First of all, pricing is an annual process. Hotel properties determine a pricing strategy and negotiate business contracts with key clients (cell 1). The regional offices communicate corporate pricing guidelines with the properties and contract business at corporate, cruise, wholesale, and consortia levels (cell 4). Head-office is involved as it approves property pricing strategies (cell 6). Secondly, room rate pricing is an on-going process at the property level comprising the day-to-day fine-tuning of room rates and the prospecting and contracting of (new) business (cell 3). These activities aim to minimize a property's opportunity costs. Thirdly, pricing is a recurring process throughout the budget year (e.g., monthly, bi-annually). At the property and regional level (new) business is contracted (cells 2,5). As property pricing strategies sometimes become no longer sustainable, they are sometimes adjusted (cell 2) and consequently approved (cell 7) during the budget year. Throughout the year individual properties receive support from head-office or the regional office (cells 5,7). At regular intervals control activities also take place at the head-office and regional level. The findings suggest that head-office is very much concerned with improving the behavior of individuals and the overall quality of pricing practices in the hotel group. Property management is primarily involved in the practical consequences of value-based pricing. Regional office is interested in both, and, therefore, seeks to maintain goal congruence. 
Figure 2: Implementing Value-Based Pricing Activities in a European Hotel Group

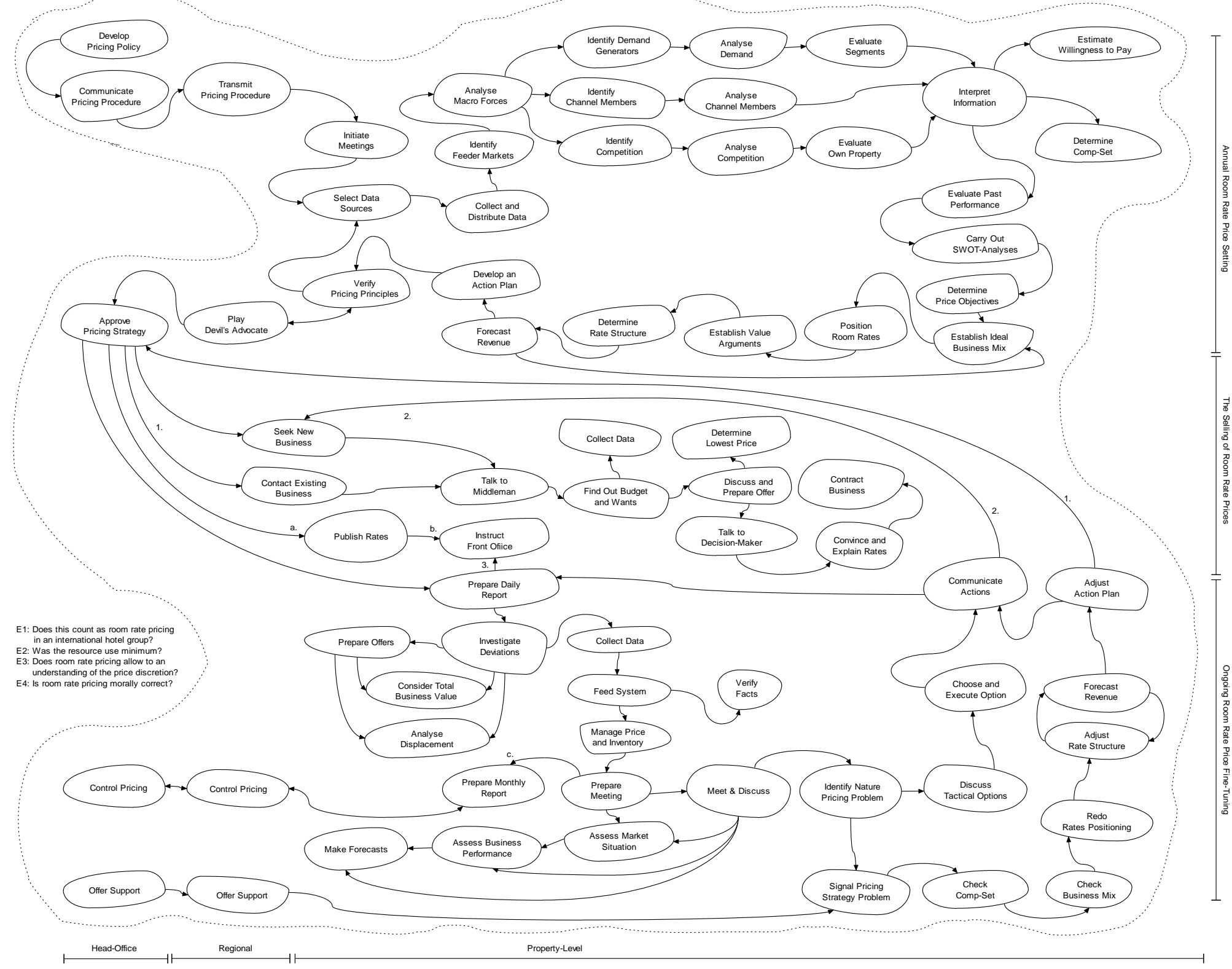


Table 2: The Resource Base for Implementing Value-Based Pricing in a European Hotel Group

\begin{tabular}{|c|c|c|c|}
\hline Spanning Activities & Tangible Resources & Relational Resources & Competences \\
\hline $\begin{array}{l}\text { 1. Developing Pricing } \\
\text { Policy, Approving } \\
\text { Pricing Strategy } \\
\text { and Offering } \\
\text { Support }\end{array}$ & $\begin{array}{l}\text { Materials: } \\
\text { - strategic pricing handbook } \\
\text { - revenue management library }\end{array}$ & $\begin{array}{l}\text { Internal Relationships: } \\
\text { - intra-organizational (property management - } \\
\text { regional management) }\end{array}$ & $\begin{array}{l}\text { Knowledge: } \\
\text { - insight in participants' preferences } \\
\text { Attitude: } \\
\text { - mindset to learn from critical comments }\end{array}$ \\
\hline $\begin{array}{l}\text { 2. Determining and } \\
\text { Adjusting Pricing } \\
\text { Strategy }\end{array}$ & $\begin{array}{l}\text { Materials: } \\
\text { - business plan } \\
\text { - budget and forecast } \\
\text { Computer Systems: } \\
\text { - rate positioning diagram } \\
\text { - rate effectiveness tool } \\
\text { - accounts performance tool } \\
\text { - stay and spend tool }\end{array}$ & $\begin{array}{l}\text { Internal relationships: } \\
\text { - team (revenue management team) } \\
\text { External relationships: } \\
\text { - direct (clients, business community, } \\
\text { government agency, rivals) } \\
\text { - inter-organizational (travel industry) }\end{array}$ & $\begin{array}{l}\text { Knowledge: } \\
\text { - competitor pricing (history), product (hard- and software), clients } \\
\text { - feeder markets, channel intermediaries and demand generators } \\
\text { - own property's relative hard- and software } \\
\text { Skills: } \\
\text { - selecting competitors, making relevant comparisons, determining } \\
\text { general price levels } \\
\text { - establishing (tacit) information sources } \\
\text { - performing financial analyses } \\
\text { - communicating price changes } \\
\text { - establishing routines to resolve goal conflicts } \\
\text { Attitude: } \\
\text { - will to commit to action plan }\end{array}$ \\
\hline $\begin{array}{l}\text { 3. Learning and Fine- } \\
\text { Tuning Prices }\end{array}$ & $\begin{array}{l}\text { Materials: } \\
\text { - revenue diary } \\
\text { - market outlook report } \\
\text { - third-party statistics } \\
\text { - Internet links } \\
\text { Computer Systems: } \\
\text { - revenue management system } \\
\text { - displacement analysis tool } \\
\text { - forecasting tool }\end{array}$ & $\begin{array}{l}\text { Internal relationships: } \\
\text { - direct (inbound-outbound sales) } \\
\text { - team (revenue management team) } \\
\text { External relationships: } \\
\text { - direct (travel industry, government agency, } \\
\text { rivals) }\end{array}$ & $\begin{array}{l}\text { Knowledge: } \\
\text { - focal points and tacit coordination } \\
\text { Skills: } \\
\text { - yielding, forecasting and managing revenue } \\
\text { - tracking and assessing competitive price information } \\
\text { Attitude: } \\
\text { - disposition to span sales and revenue concerns }\end{array}$ \\
\hline $\begin{array}{l}\text { 4. Negotiating and } \\
\text { Explaining Prices }\end{array}$ & $\begin{array}{l}\text { Materials: } \\
\text { - accounts record } \\
\text { - sales gift }\end{array}$ & $\begin{array}{l}\text { Internal relationships: } \\
\text { - direct (sales - revenue) } \\
\text { External relationships: } \\
\text { - direct (clients, travel industry) } \\
\text { Reputation: } \\
\text { - management (sales, revenue general) } \\
\text { - hotel (operations) and brand }\end{array}$ & $\begin{array}{l}\text { Knowledge: } \\
\text { - client (organizational) characteristics } \\
\text { - customer budget and wants } \\
\text { - alternative competitive offer(ing) } \\
\text { Skills: } \\
\text { - collecting and assessing customer information } \\
\text { - establishing lowest rate and negotiation strategy } \\
\text { - maintaining goal congruence (sales - revenue) } \\
\text { - educating and convincing the market } \\
\text { Attitude } \\
\text { - will to creatively and proactively close a deal }\end{array}$ \\
\hline
\end{tabular}




\section{Implementing value-based pricing activities}

In the literature it is often stressed that it is particularly complex to reflect on (room rate) pricing practice. Room rate pricing here is, therefore, examined through an analysis of the main processes employed. To delineate major processes, a number of systems models are constructed. These models are accounts of concepts of purposeful activity, and they are models relevant to the discussion of room rate pricing practices that lead to pricing decisions in a European hotel group. Through these models, three main purposeful activities are observed, each expressed by a root definition. A root definition is a notional system which is developed more fully in a conceptual model. The conceptual model represents a human activity system. A human activity system is a model of a notional system comprising the activities people in a hotel group need to undertake in order to determine room rate prices in return for the value it has created. The three main activity systems are labelled: (1) developing pricing strategy; (2) approving pricing strategy; (3) adjusting prices. These models are built as a set of linked activities and are illustrated in Figure 2. Three accolades on the right side of the figure indicate the activities that encapsulate the three main activities. On the bottom of the figure, three accolades indicate the hierarchical level at which these activities take place. The pricing activities were further analyzed and regrouped into four main dimensions in order to examine the resources that underlie value-based pricing processes. As Table 2 illustrates, various tangible and relational resources and competences were found, some being built into sources of superior performance, some hard to nullify and some central to the capture of value.

The resource-based view taken in this study acknowledges that in setting and changing prices the international hotel group needs to learn to: (a) capture value (Dutta et al., 2003); and (b) balance conflicting interest (Kaplan, Dirlam \& Lanzillotti, 1958; Hague, 1971). The resource base for pricing, therefore, consists of systems and processes that the hotel group 
develops to address both of these issues. The four main dimensions are further explained below:

$\underline{1 .}$ Developing group-wide pricing policy, approving pricing strategy and offering support;

The process of improving room rate pricing practice in the European hotel group is not an easy task. Pricing is a human interactivity process which is subject to constant change. The status quo of pricing practice was found to vary significantly in the group. The task of developing a pricing policy, approving pricing strategy, and offering support, then, is not simply a matter of establishing a corporate revenue development office. It takes time and expertise to develop corporate guidelines which are broad enough to include the multiplicity of pricing environments whilst at the same time being meaningful to a manager who faces a special pricing problem. The routines to get approval, to accept and implement a new directive, are the result of intra-organizational relationships that take years to develop. A City General Manager explains how it works:

"once agreed on this I sold them to the regional director for him to link into this and agree on the thinking [...] we will position these hotels differently and thereby get a bigger grasp of the entire market place. [...] from discussing it with the regional directors [...] we went back to the rest of the GM's in the city and director of sales and myself and we took it from there."

Understanding why participants prefer certain strategies, a mind-set to learn from critical comments, are key to building relationships in which mutual trust and respect contribute to the development of goal congruence and advanced room rate pricing practice. A Director of Sales became painfully aware of this when he commented:

"our market knowledge was right and we told people that they were not able or not willing to pay the price but they didn't listen. They thought that we could still maintain a fair occupancy with our high rates because our product was the better. But they just forgot that there is competition now that's better products and lower rates. [...] We are suffering from that now because as I said, it takes time to change the picture [...] maybe someone will have already left us and gone for their new hotel partner so it's even more difficult to get them back. So that was our big mistake." 
Findings indicate that relational resources and attitude competences are significant to all dimensions of pricing spanning processes (Day, 1994).

\section{$\underline{\text { 2. Determining and Adjusting Pricing Strategy }}$}

Similarly not straightforward is the process of collecting data. It requires mutual beneficial relationships with clients, government agencies, and the business community (including rivals) to exchange the vital information that is often only accessible to internal parties. As a Regional Director of Sales states:

"We have of course key accounts that we can approach. Some of them you drink a lot of beers with, so it's confidential. And we know some other clients that work better with us and like us better. We can ask them what kind of rates you get from that point [i.e. the competitor]. It's a bad market but that's how it works. It works like that in any market."

But, even with the right information available, it is still difficult to interpret the information and make successful pricing decisions.

The evaluation of segments, the selection of the competitive-set, and the comparison of competitive products and prices are generally the subject of considerable discussion and debate. Disputes follow naturally from goal conflicts in sales and revenue. As a Director of Sales admits 'we used to be very split and [there was] not much communication. Now we are talking all the time.' The extraction of value created, therefore, requires the building of internal relationships. General Managers need to understand the specific dimensions of goal conflicts in order to establish routines that resolve them. Moreover, it takes time to develop computer systems which support the improvement of market knowledge. Findings indicate that as a rule pricing strategies which are determined prior to the opening of a hotel have to be radically changed after a number of months due to a lack of data and familiarity with the business environment. During the field study it also became apparent that managers with a 
good reputation were also the ones who stayed at properties for some time, often more than 10 years, and as a result had developed such knowledge.

\section{Learning and Fine-Tuning Prices}

During interviews it was often remarked upon that in the process of on-going pricing 'you need ice in the stomach'. Given a focal point established through past experience of a revenue manager, and given that a hotel is reluctant to initiate downward price spirals all that is needed for coordinating tacitly is sometimes to wait and see whether a competitor is really wrong or right in their (downward) price action. Then again, the choice to wait and see may be based on the wrong information especially considering the difficulty of tracking and assessing price information. Thus, when the stakes are high the process of adjusting prices becomes a team process. One Revenue Manager expressed his appreciation for the support he received from a GM with a background in revenue management: 'he knows so much about revenue management, it's very important if you want to live'.

Participants in this process often disagree on how customers and competitors will react. It is therefore important to establish field contacts to triangulate various internal viewpoints. An expertise in managing revenue is not sufficient as empirical results indicate that revenue managers must also employ a will to integrate both sales and revenue concerns. A Director of Sales explains this attitude:

\footnotetext{
"The good times $[\ldots]$ we didn't as much ask ourselves what is it the customer wants $[\ldots]$ in bad times, we are much better at that [...] things just don't come by themselves. That's when we get good in better times. That's where we learn and where we see how things work if we lower a rate or increase a rate [...] we used to have a rate and that's take it or leave it, in good times, because we knew we could always find somebody else who wants that rate. But now we need to manage the market constantly."
}

The use of tools and materials is found to aid this process: 
"we will do a displacement analysis to control what it would do for us [...] he is staying on Monday, we need business on Mondays [...] we will go through the whole thing and see if it is worth giving you a discount $[\ldots]$ the larger the companies $[\ldots]$ it gets more serious."

Therefore, whereas those in sales might improve their knowledge of costs and revenues; revenue managers increase their scope of capabilities from solely monitoring and analyzing figures and indices to a fuller understanding of the peculiarities of market reality.

\section{Negotiating and Explaining Room Rate Prices}

Determining and adjusting prices only initiates the room rate pricing process. Hotel management knows that it also needs to 'sell' prices to customers. This is why the hotel group launches value-based guidelines:

"In this context, whenever a price is set you must be able to articulate both to your hotel team and to the customer the Value Argument that supports each rate you offer. In other words a Value Argument is the reason why the rate exists and why it differs from another rate. If there is no clear Value Argument, than the rate cannot exist" (Strategic Pricing Handbook).

To sell room rates the relationship with a client really counts:

"I think the relationship is what sells [...] People buy from you because they like me $[. .$.$] in the long run, you build up your relationship if you have the right$ products that will fit the customer's needs [...] then it is you they are buying from, it's not the product so much." (Sales Manager)

Moreover, a hotel needs to build the ability to convince the client of the logic behind its pricing strategy and fine-tuning actions. A Revenue Manager explains:

"September is going to be very strong [...] our corporate clients are our real feeder market. So they were already very much upset with summer high season months. And it took a lot of efforts from the sales team especially to prove that it's the only way they can book rooms if they accept this seasonality in pricing low season and high season. So to explain to them that September is also high season was not brilliant."

To convince a client, hotels need to also develop the capability to internally agree on contracting strategies and tactics. A city revenue manager believes that: 
"our job in revenue management is really to make sure and explain so that salespeople, they also understand [...] that you really need to optimise the revenue in the hotel [...] If you have a very, very good communication and you have very good interaction [...] when I look back [...] they just wanted to give whatever the customer said [BUT NOW] They really think it up. We need this kind of business and we need this business, what rate are we offering, how low would we actually like to go here? So I mean it's a very cooperation that we have with the sales."

Inter-functional consultation is essential in the capturing of value. As a Regional Director of

Sales explains:

"when I came on board it was more like a revenue management decision [...] the sales department [...] regionally based so they were not really physically in the hotel [...] not a lot of contact [...] I don't think that was good [...] you had more like the situation where a sales manager was calling the revenue manager, "Hi, I need a price for this customer" [...] So then the sales manager [...] got a price. And it went back to the customer [...] it doesn't train the sales manager to $[\ldots]$ think. Ideally [...] they should be able to calculate a price and then have an educational discussion with the revenue manager, the thing is that the revenue manager has $[\ldots]$ Fidelio, they know if there's room [...] or if there's not room in the hotel $[\ldots]$ so that's why they need to contact the revenue manager to see what can be offered."

It is therefore important that internal, interpersonal relationships are built which create the

trust and respect that is necessary to work and internally agree:

"we realized [...] a challenge when it comes to communication, strategies [...] the revenue manager is just looking at figures [...] has a totally different viewpoint. So, what we decided is to move together into one office." (Director of Sales)

"we are very close. The revenue management and my office, for example, it's next door. We talk all the time. I've been in this position for five years so we know how we think. So I don't have to ask them any time. I would say $80 \%$ of the cases, we all agree at a certain point [...] because I know what can sell and they don't know that." (Regional Director of Sales).

The role of general management is imperative in the process of pricing. A City General

Manager explains how he is involved at a very operational level:

"I call the editor myself and I tell him that one of my sales people will be in touch and I also tell him [...] I will be there myself and I will do everything to ensure that this banquet would be the best [...] But you can see signs that they are flattered $[\ldots]$ one telephone call $[\ldots]$ for three or four minutes $[\ldots]$ very 
polite [...] I know that none of my competitors called. I know that because they told me later when the decision was clear. And I also know that none of the competitors gave them an offer which was as clear as our offer. And that helps me. And I don't think my competitors are bad on strategy. I think they are very good on strategy. But I think they don't have the right focus on tactics."

As a former sales director knows what leadership can achieve:

"The sales people, they know me. So, if they want me to take a telephone call, I never say no. [...] I do it because if they know that I'm behind them $100 \%$ [...] they will feel secure and that's the main reason that the sales people is succeeding [...] they know that they can conquer the world by just by picking up the phone [...] I think tactics is the most important thing when you want to close a deal. Strategy is very good to have. You have to have something in the bottom. But the tactics [...] every sale is different."

His role in the management of internal interpersonal relationships creates a basis to develop and retain human capital. Something he reflected upon when referring to a competitor:

"Sheraton has a very loyal clientele [...] in the seven years that they have been here in the market they have built this kind of clientele and I really have to say it's very good work. So maybe they have a better system than we do [...] When we were opening, there were no people from Sheraton applying here [...] so it says a lot about them. How they are as an employer, how they pick people, how they pay [...] So I would say it's human capital there. And also in terms of the sales department, they haven't changed in years in that hotel" (Regional Director of Sales).

Convincing customers involves the ability to cope with the consequences of selling room rate prices to buyers who themselves may not be the (end)users and/or the final bill payers. This requires recognition and understanding as to who to target in terms of value arguments. To develop such individual skills, reliable (tacit) resources are necessary to get an accurate picture of customer's budgets, wants, and alternative competitive offers. The empirical study indicates that it is not easy to develop knowledge of middlemen and final decision-makers. It also takes time for hotel employees to be able to assess each player's reaction to a pricing action. Findings also indicate that personal reputation is vital to the process of convincing and negotiation. When the hotel industry is in decline relationships often form the basis for convincing clients that the brand's expensive reputation (resulting from revenue maximizing 
behavior in good times) is no longer accurate. As a final point, when a sale is in progress the entire hotel must be in sales mode, including operations:

\begin{abstract}
"they are in the sales process $[\ldots]$ afterwards, you can tell them $[\ldots]$ "some of the reason he chose the hotel was that he met a lot of very nice people on the site inspection" $[\ldots]$ then you have a very good communication. And they feel involved. They really don't do that much but they smile and they are there and if there is something [...] they feel it more because somebody has given their trust." (Regional General Manager)
\end{abstract}

To set and change a rate is relatively straightforward. From a resource-based view, however, the challenge is to extract value by making superior room rate decisions across a variety of room offerings, business mixes, and against a relevant set of competitors. To develop a superior understanding of the room rate price discretion it is not enough to issue company guidelines. It requires the simultaneous development of human, social, and infrastructural capital. Evidence suggests that the hotel group has mostly invested in tangible resources. It has made human investments to the extent that it has (only) trained property management to work with the tangible pricing resources. Using an analogy that refers to the belief that restaurants represent an opportunity cost, a Regional Director expresses doubts about this approach:

"what we do, we keep the people, we change the menus [...] we fix up the restaurant but we keep people. We change the menus, we fix up the restaurant but we keep the people. I think one really has to think about do we have the people for the future?"

In his opinion the group has not differentiated between aspects that can be trained and those that come from a person's social, educational or professional background. Finally, less attention has been paid to investments in relational capital. Regarding the extent to which investments were made, it can be observed that these were mainly made at the property level (i.e. the general manager), and to a lesser extent at the regional level. The next section discusses the findings against previous research. 


\section{Discussion}

As the main interest of the study is in system analysis it should be reiterated, however, that the main purpose of the research is to depict a real system in a systems model without changing the system, and to clarify which internal or external factors influence the system (Arbnor and Bjerke, 1997). Contrary to the analytical approach, the empirical literature will mostly be used to explore and arrive at new ways of approaching or classifying reality (rather than to determine reality more precisely). Instead of utilizing the literature to discuss the generalization of empirical findings based on a sample of representative cases, this chapter, therefore, explicitly uses the literature, and the theoretical propositions (See Section 3.6, p. 107), as a conceptual framework to obtain a better description and understanding of the real system, i. e. room rate pricing practice in a European hotel group. One key theme which has emerged from the data presented above is the nature and. scope of constraints in the process of room rate pricing is examined to gain an understanding of how these constraints influence the approach of head-office to develop and improve pricing in the hotel group. The section discusses the research findings related to four key processes in pricing practice: 1 . obtaining data to make pricing decisions; 2. measuring and quantifying a multitude of factors; 3. making a final decision based on incomplete evidence; and 4. the selling, negotiating, convincing and explanation of prices.

\section{Obtaining data to make value-based pricing decisions}

Studies of data-based pricing approaches have been a popular research topic in the literature (e.g., Noble \& Gruca, 1999; Cressman, 1999; Avlonitis \& Indounas, 2005). There is, however, little research that addresses the problem of obtaining data, especially in the area of capacity constrained perishable revenue management. In particular, this study found that the process of obtaining customer-related data poses a great constraint on differential pricing. 
Inherent time pressures, heterogeneous and dynamic demand put significant restrictions on data gathering. The data gathering process involves iterative processes of sensing, collecting and triangulating data calling for experience, a strategic network of contacts and a wide range of informal external relationships all of which cannot be developed without investing significant resources over time. With similarities to Oxenfeldt (1973), a major challenge observed in value-based pricing is the development of intangible resources that enable the gathering of a mix of implicit and explicit information coming from a wide range of formal, informal and the more subtle sources of information. It requires, for example, a significant investment in teamwork/skill to establish an effective mix of (tacit) information sources that is often only available to insiders. Dutta et al. (2003) refer to these resources as a series of nested routines, skills/know-how and coordination mechanisms. This study draws attention to the significance of relational resources, such as relationships with external clients or the travel industry, especially in the process of obtaining demand and customer-related pricing information. It suggests that outside-in data collection processes are relatively important to the setting and fine-tuning of value-based prices in the international hotel group. Unlike the findings of Dutta et al. (2003) and Myer (1997), property management was found to be very capable and resourceful in the process of obtaining competitor information, not experiencing any particular difficulty or complexity in the data collection practice. It is the process of gathering demand-related information (e.g., on customer value, key clients' budgets and wants, channel intermediaries, demand generators) that presents the major challenge. Strategic investments in the market sensing system, specifically intangible relational resources, appear to be most crucial in the process of collecting pricing information. As these social processes and assets are not easily imitated, traded for, or substituted for without investing significant resources over time, this study extends the work of Koufteros et al. (2002), Dutta et al. (2003), Morgan et al. (2009), Liozu et al. (2011) and Liozu and Hinterhuber (2014) by suggesting that 
data collection processes and resources in a value-informed pricing policy comprise a specific capability.

\section{Measuring and quantifying a multitude of factors}

The pricing literature emphasizes the precision of the cost estimate and the significance of cost data as particularly influential in how industrial firms set prices (Bonoma et al., 1988). In this regard, competitive price information is also frequently mentioned. The findings indicate that cost-/competitor-informed is also used because managers: (1) doubt whether customers perceive the value base they set up for them, (2) feel that they do not possess the resources to measure and quantify customer-value, and (3) know that estimating and quantifying pricing data involves resolving and avoiding disputes. This is an important empirical result as Ingenbleek (2002) found that in markets with high demand uncertainty, value extraction to a large degree is rooted in customer orientation.

Along the lines of Dutta et al. (2003), considerable debate was found about whether specific attributes (e.g., bathrobes or slippers) are of value to customers, and, if agreed on, how much they would pay for these attributes separately, and in total. This uncertainty is explained by Goldberg et al. (1984) who found that self-explicated utilities for bundle components are no good predictors of a preference for the total bundle of hotel amenities. To make assumptions and conjectures the view of sales managers is considered because of their market knowledge (Farley et al., 1980). Revenue managers, key in the process of setting room rates, however, favor factual data. They focus on past room rates, occupancies and competitor prices as their responsibilities pull them toward the inside-out end of spanning processes (Day, 1994). Too much outside-in thinking was found to give rise to severe employee morale problems, customer alienation, price unfairness, and unacceptable practices such as imposing too severe restrictions on discounts (e.g., Kimes, 1989a/b, 1994, 2002; Oh, 2000; Oh \& Jeong, 2004). Sales managers, who are primarily involved in market sensing, negotiating, and 
explaining prices, are drawn to the outside-in end of the orientation spectrum. The findings indicate that the credibility of the sales manager is significant in the process of agreeing about assumptions and conjectures. Such trust is not easily earned and commonly requires developing a track record based on long-standing experience, and a thorough understanding of the specifics of the market. As credibility is not easily warranted, it is suggested that the measurement and quantification of customer-related information requires the development of a sales spanning competence. This suggestion extends the research of Brandenburger and Stuart (1996) who argue that a (sales) competence is first and foremost a requisite to succeed in bargaining (rather than a resource to internally bring value-based pricing in line with market realty).

\section{Making a Final Decision Based on Incomplete Evidence}

Little previous research addresses the importance of the team decision-making process (Farley et al., 1980). The findings suggest that general managers act as mediators assisting sales managers to understand revenue management aspects of a price decision and vice versa. The pattern of decision-making in these teams can be characterized as 'developing trust and productivity' or 'working to a common goal on a co-operative basis'. When a single function dominates, it can be characterized as 'pretending to get along with each other' or 'getting down to issues at the risk of creating a conflict'. Under these circumstances, a revenue manager's attitude to discuss a sales mistake (e.g., a bad judgment caused by poor reasoning) can for example have a strong influence on whether a sales manager will come forward and admit an error the next time. A disposition to consider sales problems not as a mutual problem was also found to lead to serious group decision-making problems and a serious lack of goal congruence.

Without 'the internal glue that coordinates and holds together the many participants in the pricing process' (Dutta et al., 2002, p.13) it was found that the functioning of property-level 
decision processes yields in competitive-based prices. In this context, the findings indicate that the position of General Manager is important for two reasons. First of all, it increases the ability of a team to converge on a final price choice on the basis of incomplete evidence with the support of each participant in the pricing system. It paves the way for a more informed approach to room rate pricing decision-making in which both inside-out and outside-in views on pricing receive sufficient attention. It thereby precludes pricing decision-making from becoming either a feedback-control system triggered by exogenous factors (Farley et al., 1971) or a purely sales-oriented pricing system which is solely fed by a suboptimal desire to serve additional customer segments (Enz et al., 1999). Secondly, it facilitates the development of experiential learning processes (Carson et al., 1998) which encourages the evaluation of pricing decision making. Learning processes are very important to value-based pricing as evidence is frequently incomplete or absent, and problems in pricing can often only be sorted out and solved by means of experiment (Diamantopoulos, 1989). Especially in economically difficult times with a great deal of pressure coming from the market, competition, and headoffice it is evident that conflict resolution activities play a vital role as to general, sales and revenue management goals and responsibilities (Farley et al., 1980). Therefore, along the lines of Capon et al. (1975) the findings suggest that interpersonal and political realities impose major effects on the pricing decision-making process. These social effects particularly concern making a final price choice and the orientation and focus of room rate pricing processes.

\section{Selling, Negotiating and Explaining Prices}

Brandenburg and Stuart (1996) suggest that the capturing of value also depends on a firm's ability to bargain. Dutta et al. (2003) extend this argument by illustrating that firms need a pricing-setting capability vis-à-vis customers (i.e. to 'sell' the prices to customer). 
When a rate (structure) is adjusted managers are keen to foster relationships by explaining price changes to customers, competitors and third-party distributors. Revenue managers consider corporate guidelines useful as they provide a rational behind explaining prices to customers. To sales managers, the sale and explanation of prices is more a matter of granting each other something and finding gains for both sides of the relationship. In selling and explaining prices sales managers typically focus on a much longer term than revenue managers. In this context, sales managers can get into precarious situations when customers do not accept price offers whilst running out of arguments to convince the revenue manager to agree about lower room rate price offers. The findings indicate that the ability to sell, negotiate and explain prices largely depends on an ability to agree internally. Forming dialogues is fundamental in this process. Dutta et al. (2003) emphasize the role of reputation and strong ties which make easier negotiations and better terms possible. This study found that the operations side of a property significantly adds to the creation of reputation and trust. The contracting process is not determined by those in sales alone, but benefits from a cooperation between managers in sales, operations, revenue and general management.

\section{Conclusion}

Drawing from the resource-based view in strategy, and thereby introducing a new theoretical perspective to the study of room rate pricing, it can be concluded that while the European hotel group thought it was implementing a (new) value-driven pricing policy, in reality it kept with, and still thought and acted in, the (old) competitor-oriented way. In a company employing a centralized process, it went unrecognized that routines, resources and the organizational context were important in leading to success in a policy change. While project investments were made to implement the change, a far greater strategic allocation of resources in technical, human and social capability was needed to become value-driven in the commoditized and highly competitive business environment of the European hotel group. 
The findings of this study suggest that the determination of room rate prices in an European hotel group involves a complex system of activities that can be regrouped into four major spanning processes: (a) developing pricing policy, approving pricing strategy and offering support; (b) determining and adjusting pricing strategy; (c) learning and fine-tuning prices; and (d) negotiating and explaining prices. The purpose of these processes is to integrate inside-out and outside-in processes that guide and inform pricing decision-making. The study shows how information constraints, tensions and goal conflicts in the determination of prices affect the four spanning processes and, hence, the development of value-informed pricing practice in a European hotel group. These constraints involve a lack of credible information on demand and especially customer value, the problem of interpreting this information, and an absence of routines to make final price decisions based on incomplete evidence with multiple and uncertain decision outcomes. As a result, pricing remains largely competitor-oriented. The tensions and goal conflicts involve the way in which sales and revenue managers co-operate. They start during the process of determining and approving the pricing strategy, and continue in the process of learning and fine-tuning, and negotiating with and explaining prices to key accounts and the travel industry. The root of these tensions is undoubtedly a lack of goal congruence between sales and revenue management.

As with all research this study is not without limitations. Whereas the utilization of a case study strategy offers rich contextual understanding, it is also limited to a European hotel group. Moreover, its cross-sectional design may have restricted identification or analysis of some important themes in the pricing process which possibly would have emerged if the study had opted for a longitudinal data structure. Moreover, due to confidentiality restrictions, the study data have remained unpublished for some years, and, consequently, recent developments were not captured by the case study. In addition, the study is also limited in its relationships to the external environment. 
Further research could be carried out into the specific backgrounds and personalities of the team players and how these influence the pricing process and, more importantly, the development of (in)tangible resources. It could also be worthwhile to study how the strategic resource allocation or investment policy of an organization affects the development of pricing resources and, ultimately, their impact on financial performance. Within this context, future studies could investigate if and why value-based pricing in one industry is more difficult and complex and, hence, more in need of a strategic investment in resources, than value-based pricing in other industries. Research could then focus on how managers in various industries overcome (some of) their problems and to what extent this includes experiential learning processes, especially in the context of sales-revenue (departmental) relationships.

\section{References}

Abrate, G., and Viglia, G. (2016). Strategic and tactical price decisions in hotel revenue management. Tourism Management, 55, pp. 123-132.

Abrate, G., Fraquelli, F. and Viglia, G. (2012). Dynamic pricing strategies: Evidence from European hotels. International Journal of Hospitality Management, 31(1), pp. 160-168.

Abratt, R. and Pitt, L.F. (1985). Pricing Practices in Two Industries. Industrial Marketing Management, 14(4), pp. 301-306.

Avlonitis, G.J. and Indounas, K.A. (2005). Pricing Objectives and Pricing Methods in the Services Sector. Journal of Services Marketing, 19(1), pp. 47-57.

Baum, T. and Mudambi, R. (1995). An Empirical Analysis of Oligopolistic Hotel Pricing. Annals of Tourism Research, 22(3), pp. 501-516.

Becerra, M., Santaló, J. and Silva, R. (2013). Dynamic pricing strategies: Evidence from European hotels. International Journal of Hospitality Management, 31(1), pp. 160-168.

Blyler, M. and Coff, R.W. (2003). Dynamic capabilities, social capital, and rent appropriation: Ties that split pies. Strategic Management Journal, 24, pp. 677-686.

Bonoma, T.V., Crittenden, V.L., and Dolan, R.J. (1988). Can we have Rigor and Relevance in Pricing Research? In: Devinney, T.M., (ed.) Issues in Pricing: theory and research. Toronto: Lexington Books, pp. 337-359. 
Brandenburger, A.M. and Stuart, H.W. (1996). Value-Based Business Strategy. Journal of Economics and Management Strategy, 5(1), pp. 5-24.

Capon, N., Farley, J.U., and Hulbert, J.M. (1975). Pricing and Forecasting in an Oligopoly Firm. Journal of Management Studies, 12(2), pp. 133-156.

Carson, D., Gilmore, A., Cummins, D., Donnel, A.O., and Grant, K. (1998). Price Setting in SMEs: some empirical findings. Journal of Product and Brand Management, 7(1), pp. 74-86.

Checkland, P.B. (2003). Soft Systems Methodology: a 30-year retropective. Chichester: John Wiley \& Sons Ltd.

Churchman, C.W. (1979). The Systems Approach and its Enemies. New York: Basic Books.

Cressman Jr., G.S. (1999). Commentary on Industrial Pricing: theory and managerial practice. Marketing Science, 18(3), pp. 455-457.

Cross, R., Higbie, J. and Cross, D. (2009). Revenue management's renaissance: A rebirth of the art and science of profitable revenue generation. Cornell Hospitality Quarterly, 50(1), pp. 56-81.

Cyert, R.M. and Hedrick, C.L. (1972). Theory of the Firm: past, present, and future. Journal of Economic Literature, 10(2), pp. 398-412.

Day, G.S. (1994). The Capabilities of Market-driven Organizations. Journal of Marketing, 58(10), pp. 37-52.

Dean, J. (1949). Cost Forecasting and Price Policy. Journal of Marketing, 13(3), pp. 279-288.

Diamantopoulos, A. (1989). Price Decision-Making in a Multiproduct Firm: an empirical analysis. PhD, University of Strathclyde.

Diamantopoulos, A. and Mathews, B.P. (1995). Making Pricing Decisions: a study of managerial practice. London: Chapman \& Hall.

Dunn, K.D. and Brooks, D.E. (1990). Profit Analysis: beyond yield management. Cornell Hotel and Restaurant Administration Quarterly, 30(2), pp. 23-34.

Dutta, S., Bergen, M., Levy, D., Ritson, M., and Zbaracki, M. (2002). Pricing as a Strategic Capability. Sloan Management Review, 43(3), pp. 61-66.

Dutta, S., Zbaracki, M., and Bergen, M. (2001). Pricing Process as a Capability: a case study. Report no 01-117, Marketing Science Institute, Unpublished.

Dutta, S., Zbaracki, M.J., and Bergen, M. (2003). Pricing Process as a Capability: a resourcebased perspective. Strategic Management Journal, 24(7), pp. 615-630.

Earl, P.E. (1990). Normal Cost versus Marginalist Models of Pricing: A Behavioral Perspective. Journal of Post Keynesian Economics, 13(2), pp. 264-281.

Enz, C.A., Canina, L. and Lomanno, M.V. (2004). Why Discounting doesn't Work. The Center for Hospitality Research. Report: 4/7, Cornell University, pp. 1-28. 
Enz, C.A., Canina, L., and Van der Rest, J.I. (2016). Hotel Strategic Pricing in Europe: a 10year exploration of competition. International Journal of Revenue Management, 9(2-3), pp. 92-107.

Enz, C.A., Potter, G., and Siguaw, J.A. (1999). Serving More Segments and Offering More Products. Cornell Hotel and Restaurant Administration Quarterly, 40(6), pp. 54-63.

Erdem, M., and Jiang, L. (2016). An overview of hotel revenue management research and emerging key patterns in the third millennium. Journal of Hospitality and Tourism Technology, 7(3), pp. 300-312.

Farley, J.U., Howard, J.A., and Hulbert, J.M. (1971). An Organizational Approach to an Industrial Marketing Information System. Sloan Management Review, 13(1), pp. 35-54.

Farley, J.U., Hulbert, J.M., and Weinstein, D. (1980). Price Setting and Volume Planning by two European Industrial Companies: a study and comparison of decision processes. Journal of Marketing, 44(1), pp. 46-54.

Flood, R.L. and Jackson, M.C. (1991). Creative Problem Solving: total systems intervention. Chichester: John Wiley \& Sons Ltd.

Gu, Z. (1997). Proposing a Room Pricing Model for Optimizing Profitability. International Journal of Hospitality Management, 16(3), pp. 273-277.

Guo, X., Ling, L., Dong, Y. and Liang, L. (2013). Cooperation contract in tourism supply chains: the optimal pricing strategy of hotels for cooperative third party strategic websites. Annals of Tourism Research, 41, pp. 20-41.

Goldberg, S.M., Green, P.E., and Wind, Y. (1984). Conjoint Analysis of Price Premiums for Hotel Amenities. Journal of Business, 57(1, part 2), pp. 111-132.

Hague, D.C. (1971). Pricing in Business. London: George Allen \& Unwin Ltd.

Hall, R.L. and Hitch, C.J. (1939). Price Theory and Business Behavior. Oxford Economic Papers, 2(May), pp. 12-45.

Hallberg, N.L. (2017). The micro-foundations of pricing strategy in industrial markets: A case study in the European packaging industry. Journal of Business Research, in press.

Hamel, J., Dufour, S., and Fortin, D. (1993). Case Study Methods. Thousand Oaks, CA: Sage.

Harré, R. (1986). Varieties of Realism. Oxford: Blackwell.

Hinterhuber, A., and Liozu, S.M. (2017). Editorial: The micro-foundations of pricing. Journal of Business Research, in press.

Hunt, S.D. (2002). Foundations of Marketing Theory: toward a general theory of marketing. Armonk: M.E. Sharpe.

Ingenbleek, P.T.M. (2002). Money for Value: pricing from a resource-advantage perspective. $\mathrm{PhD}$, Tilburg University (CentER). 
Ingenbleek, P.T.M. (2007). Value-informed pricing in its organizational context: literature review, conceptual framework, and directions for future research. Journal of Product \& Brand Management, 16(7), pp. 441-458.

Ingenbleek, P.T.M. (2014). The theoretical foundations of value-informed pricing in the service-dominant logic of marketing. Management Decision, 52(1), pp. 33-53.

Ingram, H. (1999). Hospitality: a framework for a millennial review. International Journal of Contemporary Hospitality Management, 11(4), pp. 140-147.

Jackson, M.C. (1993). The System of Systems Methodology: a guide to researchers. Journal of the Operational Research Society, 44(2), pp. 208-209.

Jackson, M.C. (2000). Systems Approaches to Management. New York: Kluwer/Plenum.

Jackson, M.C. and Keys, P. (1984). Towards a System of Systems Methodologies. Journal of the Operational Research Society, 35(6), pp. 473-486.

Kaplan, A.D.H., Dirlam, J.B., and Lanzillotti, R.F. (1958). Pricing in Big Business.

Washington D.C.: Brookings Institution.

Kemper, J., Engelen, A. and Brettel, M. (2011). How top management's social capital fosters the development of specialized marketing capabilities: A cross-cultural comparison. Journal of International Marketing, 19(3), pp. 87-112.

Kim, W.G., Han, J.H., and Kyun, K. (2004). Multi-stage Synthetic Hotel Pricing. Journal of Hospitality and Tourism Research, 28(2), pp. 166-185.

Kimes, S.E. (1989a). The Basics of Yield Management. Cornell Hotel and Restaurant Administration Quarterly, 30(3), pp. 14-19.

Kimes, S.E. (1989b). Yield Management: a tool for capacity-constrained service firms. Journal of Operations Management, 8(4), pp. 348-363.

Kimes, S.E. (2002). Perceived Fairness of Yield Management. Cornell Hotel and Restaurant Administration Quarterly, 43(1), pp. 21-30.

Kimes, S. E. (2016). The evolution of hotel revenue management. Journal of Revenue and Pricing Management, 15(3-4), pp. 247-251.

Koufteros, X.A., Vonderembse, M.A. and Doll, W.J. (2002). Integrated product development practices and competitive capabilities: the effects of uncertainty, equivocality, and platform strategy. Journal of Operations Management, 20(4), pp. 331-355.

Lancioni, R., Schau, H.J. and Smith, M.F. (2005). Intraorganizational Influences on Businessto-Business Pricing Strategies: a political economy perspective. Industrial Marketing Management, 34(2), pp. 123-131.

Lee, S.H. (2016). How hotel managers decide to discount room rates: A conjoint analysis. International Journal of Hospitality Management, 52, pp 68-77. 
Lewis, R.C. and Shoemaker, S. (1997). Price-Sensitivity Measurement. Cornell Hotel and Restaurant Administration Quarterly, 38(2), pp. 44-54.

Liozu, S.M., Boland, R., Hinterhuber, A. and Perelli, S. (2011). Industrial Pricing Orientation: The Organizational Transformation to Value-Based Pricing. Proceedings of the First International Conference on Engaged Management Scholarship, 2-5 June, Case Western Reserve University, Cleveland, US.

Liozu, S.M. and Hinterhuber, A. (2013). Pricing orientation, pricing capabilities, and firm performance. Management Decision, 51(3), pp. 594-614.

Liozu, S.M. and Hinterhuber, A. (2014). Pricing capabilities: the design, development, and validation of a scale. Management Decision, 52(1), pp.144-158.

Maxwell, J.A. (1996). Qualitative Research Design: an interactive approach. Thousand Oaks,CA: Sage.

Monroe, K.B. and Mazumdar, T. (1988). Pricing-Decision Models: recent developments and research opportunities. In: Devinney, T.M., (ed.) Issues in Pricing: theory and research. Toronto: Lexington Books, pp. 361-388.

Morgan, N., Vorhies, D. and Mason, C. (2009). Market orientation, marketing capabilities, and firm performance. Strategic Management Journal. 30(8), pp. 909-920.

Morgenroth, W.M. (1964). A Method for Determining Price Determinants. Journal of Marketing Research, 1(3), pp. 17-26.

Morris, T. and Wood, S. (1991). Testing the Survey Method: continuity and change in British industrial relations. Work Employment Society, 5(2), pp. 259-282.

Nimer, D.A. (1971). There's More to Pricing than Most Companies Think. In: Vernon, I.R. and Lamb Jr., C.W., (eds.) The Pricing Function: a pragmatic approach. Lexington, MA: Lexington, pp. 19-33.

Noble, P.M. and Gruca, T.S. (1999). Industrial Pricing: theory and managerial practice. Marketing Science, 18(3), pp. 435-454.

Noone, B.M. and McGuire, K.A. (2013). Pricing in a social world: The influence of non-price information on hotel choice. Journal of Revenue and Pricing Management, 12(5), pp. 385401.

Oh, H. (2000). The Effect Of Brand Class, Brand Awareness, And Price On Customer Value And Behavioral Intentions. Journal of Hospitality and Tourism Research, 24(2), pp. 136-162.

Oh, H. (2003). Price Fairness and its Asymmetric Effects on Overall Price, Quality, and Value Judgments: the case of an upscale hotel. Tourism Management, 24(4), pp. 387-399.

Oh, H. and Jeong (2004). An Extended Process of Value Judgment. International Journal of Hospitality Management, 23(4), pp. 343-362.

Oxenfeldt, A.R. (1960). Multistage Approach to Pricing. Harvard Business Review, 38(4), pp. 125-133. 
Oxenfeldt, A.R. (1973). A Decision-Making Structure for Price Decisions. Journal of Marketing, 37(1), pp. 48-53.

Patton, M.Q. (1990). Qualitative Evaluation and Research Method. Thousand Oaks, CA: Sage.

Pellinen, J. (2003). Making Price Decisions in Tourism Enterprises. International Journal of Hospitality Management, 22(2), pp. 217-235.

Raviv, A. (1984). Comments on "Economic Foundations for Pricing. Journal of Business, 57(1, part 2), pp. 35-38.

Repetti, T., Roe, S. and Gregory, A. (2015). Pricing strategies for resort fees: consumer preferences favor simplicity, International Journal of Contemporary Hospitality Management, 27(5), pp.790-809.

Rogers, A.N. (1995). Pricing Practices in Tourist Attractions: an investigation into how pricing decisions are made in the UK. Tourism Management, 16(3), pp. 217-224.

Saunders, M.N.K., Lewis, P., and Thornhill, A. (2000). Research Methods for Business Students. Harlow: Pearson Education Ltd.

Sharp, D.J. (1994). The Effectiveness of Routine-Based Decision Processes: the case of international pricing. Journal of Socio-Economics, 23(1-2), pp. 131-147.

Shaw, M. (1984). An Analysis of the Hotel Room Rate Pricing Decision (Unpublished doctoral thesis). Cornell University, Ithaca, USA.

Solberg, C.A., Stottinger, B. and Yaprak, A (2006). A Taxonomy of the Pricing Practices of Exporting Firms: evidence from Austria, Norway, and the United States. Journal of International Marketing, 14(1), pp. 23-48.

Stake, R.E. (2000). Case Studies. In: Denzin, N.K. and Lincoln, Y.S., (eds.) The Sage Handbook of Qualitative Research. Thousand Oaks,CA: Sage, pp. 443-466.

Strauss, A.L. and Corbin, J. (1998). Basics of Qualitative Research: techniques and procedures for developing grounded theory. Thousand Oaks,CA: Sage.

Töytäri, P., Keränen, J., and Rajala, R. (2017). Barriers to implementing value-based pricing in industrial markets: A micro-foundations perspective. Journal of Business Research, in press.

Tso, A. and Law, R. (2005). Analysing the online pricing practices of hotels in Hong Kong. International Journal of Hospitality Management, 24(2), pp. 301-307.

Tsoukas, H. (1989). The Validity if Ideographic Research Explanations. Academy of Management Review, 14(4), pp. 551-561.

Tzokas, N., Hart, S., Paraskevas, S., and Saren, M. (2000). Industrial Export Pricing Practices in the United Kingdom. Industrial Marketing Management, 29(3), pp. 191-204. 
Udell, J.G. (1964). How Important Is Pricing in Competitive Strategy? Journal of Marketing, 28(1), pp. 44-48.

Van der Rest, J.I. and Roper, A.J. (2013). A resource-advantage perspective on pricing: shifting the focus from ends to means-end in pricing research? Journal of Strategic Marketing Management, 21(6): 484-498.

Vorhies, D.W. (1998). An investigation of the factors leading to the development of marketing capabilities and organizational effectiveness. Journal of Strategic Marketing, 6, pp. $3-23$.

Vorhies, D.W. and Harker, M. (2000). The capabilities and performance advantages of market-driven firms: An empirical investigation. Australian Journal of Management, 25, pp. 145-171.

Vorhies, D.W. and Morgan, N.A. (2005). Benchmarking marketing capabilities for sustainable competitive advantage. Journal of Marketing, 69(1), pp. 80-94.

Vorhies, D.W., Morgan, R.E. and Autry, C.W. (2009). Product-market strategy and the marketing capabilities of the firm: Impact on market effectiveness and cash flow performance. Strategic Management Journal, 30, pp. 1310-1334.

Walters, P.G.P. (1989). A Framework for Export Pricing Questions. Journal of Global Marketing, 2(3), pp. 95-111.

Wang, X.L., Heo, C.Y., Schwartz, Z., Legohérel, P. and Specklin, F. (2015). Revenue Management: Progress, Challenges, and Research Prospects. Journal of Travel \& Tourism Marketing, 32(7), pp. 797-811.

Yin, R.K. (2014). Case Study Research: design and methods. Thousand Oaks, CA: Sage.

Zhang, H., Zhang, J., Lu, S., Cheng, S. and Zhang, J. (2011). Modeling hotel room price with geographically weighted regression. International Journal of Hospitality Management, 30(4), pp. 1036-1043.

Zhang, Z., Ye, Q. and Law, R. (2011). Determinants of hotel room price: An exploration of travelers' hierarchy of accommodation needs. International Journal of Contemporary Hospitality Management, 27(5), pp. 972-981.

Zou, S., Fang, E. and Zhao, S. (2003). The effect of export marketing capabilities on export performance: an investigation of Chinese exporters. Journal of International Marketing, 11(4), pp. 32-55. 